\title{
Genetic variability and inheritance to aluminum tolerance in nutrient solution in triticale
}

\author{
Allan Henrique Silva $\left({ }^{(*}\right)$; Maria Elisa Ayres Guidetti Zagatto Paterniani('); \\ Carlos Eduardo de Oliveira Camargo( $\left.{ }^{2}\right)$ \\ (') Instituto Agronômico, IAC, Centro de Análise e Pesquisa Tecnológica do Agronegócio de Grãos e Fibras, Avenida Barão de Itapura \\ 1481, 13020-902 Campinas (SP), Brasil. \\ (2) In memoriam. \\ ${ }^{*}$ ) Corresponding author: allanhenrique_agron@yahoo.com.br
}

Received: May 29, 2013; Accepted: January 9, 2014

\begin{abstract}
Triticale has shown different behavior to aluminum toxicity $\left(A 1^{3+}\right)$ when applied nutrient solution. This study had the objective of evaluating 19 triticale lines inserted at International Maize and Wheat Improvement Center (CIMMYT), IAC-5 cultivar and two control cultivars of wheat in the presence of 0, 3, 6, 9, 12 and $15 \mathrm{mg} \mathrm{L}^{-1}$ of $\mathrm{Al}^{3+}$. Afterwards, four genotypes being two tolerant and two sensitive were chosen to obtain the $F_{1}$ 's, $F_{2}{ }_{2}{ }^{\prime}, R C_{1}$ 's and $R_{2}{ }_{2}$ 's generations, in all possible crossing. The seedlings were submitted to $6 \mathrm{mg} \mathrm{L}^{-1}$ of $\mathrm{Al}^{3+}$ and analyzed later on (tolerant and sensitive) by the chi-square method. The root growth was also obtained to estimate the genetic parameters involved in the character control. The trials were carried out in laboratories, in nutritive solution. The genotypes were tolerant to $15 \mathrm{mg} \mathrm{L}^{-1}$ of $A l^{3+}$, exception the line $14\left(\mathrm{P}_{3}\right)$, sensitive to $3 \mathrm{mg} \mathrm{L}^{-1}$ of $\mathrm{Al}^{3+}$ and the line 13, 17 and the cultivar IAC-5 $\left(\mathrm{P}_{4}\right)$, sensitive to $6 \mathrm{mg} \mathrm{L}^{-1}$ of $\mathrm{Al}^{3+}$, the line 15 sensitive to $12 \mathrm{mg} \mathrm{L}^{-1}$ of $\mathrm{Al}^{3+}$ and the lines 16 and 18 sensitive to $15 \mathrm{mg} \mathrm{L}^{-1}$ of $\mathrm{Al}^{3+}$. It was concluded that the inheritance to tolerance to aluminum toxicity is dominant and governed by a pair of alleles. The genetic parameters involved in the root growth control in solution containing $6 \mathrm{mg} \mathrm{L}^{-1}$ of $\mathrm{Al}^{3+}$ also revealed simple inheritance, suggesting a selection in the first segregating generations.
\end{abstract}

Key words: $X$ triticosecale Wittmack, genotypes, genetic inheritance and genetic parameters.

\section{Variabilidade genética e herança da tolerância ao alumínio em solução nutritiva em triticale}

\section{Resumo}

Apesar da rusticidade apresentada pelo centeio, o triticale tem demonstrado comportamento diferenciado na presença do alumínio $\left(\mathrm{A}^{\mathrm{l}^{3+}}\right.$ em solução nutritiva. O objetivo foi avaliar 19 linhagens de triticale do Centro Internacional de Melhoramento de Milho e Trigo (CIMMYT) introduzidas e a cultivar IAC-5 na presença de 0, 3, 6, 9, 12 e $15 \mathrm{mg} \mathrm{L}^{-1}$ de $\mathrm{Al}^{3+}$. Posteriormente, foram escolhidos quatro genótipos, dois tolerantes e dois sensíveis, para obtenção das gerações $F_{1}$ 's, $F_{2}$ 's, $R C_{1}$ 's e $R C_{2}$ 's. As plântulas foram submetidas a $6 \mathrm{mg} \mathrm{L}^{-1}$ de $\mathrm{Al}^{3+}$ e posteriormente analisadas (tolerantes e sensíveis) pelo teste de qui-quadrado. O comprimento da raiz também foi obtido, para estimarem-se os parâmetros genéticos envolvidos no controle do caráter. Os experimentos foram conduzidos em laboratório, empregando-se solução nutritiva. Os genótipos avaliados, com exceção do $14\left(P_{3}\right)$, sensível a $3 \mathrm{mg} \mathrm{L}^{-1}$ de $A^{3+}$, do 13 , do 17 e da cultivar IAC-5 $\left(P_{4}\right)$, sensíveis a $6 \mathrm{mg}$, da linhagem 15, com sensibilidade a $12 \mathrm{mg}$, e das linhagens 16 e 18, sensíveis a $15 \mathrm{mg}$, foram tolerantes a $15 \mathrm{mg} \mathrm{L}^{-1}$ de $\mathrm{Al}^{3+}$. $\mathrm{O}$ estudo da herança da tolerância à toxicidade apontou que o $\mathrm{P}_{1}$ e $\mathrm{P}_{2}$, tolerantes ao alumínio, diferiram do $\mathrm{P}_{3}$ e $\mathrm{P}_{4}$, sensíveis, por um par de alelos dominantes. Os parâmetros genéticos envolvidos no controle do comprimento da raiz em solução contendo $6 \mathrm{mg} \mathrm{L}^{-1}$ de $\mathrm{Al}^{3+}$ também revelaram herança simples, sugerindo seleção nas primeiras gerações segregantes.

Palavras-chave: $\mathrm{X}$ triticosecale Wittmack, genótipos, herança genética e parâmetros genéticos.

\section{INTRODUCTION}

The interespecific crosses carried out artificially between the genus Triticum with Secale cereale L., gave rise to the triticale (X triticosecale Wittmack), which added important characteristic from their parents, such as the increased production of wheat grain and resistance to biotic and abiotic characteristics with the low demanding in soil fertility of rye (Baier, 1999).
Genotypes of triticale have demonstrated different reaction in the presence of $\mathrm{Al}^{3+}$ toxicity in trials using nutrient solution (Camargo et al., 2006; Niedziela et al., 2012). This technique has been used in winter cereal breeding programs due to the difficulty presented to evaluate the tolerance to $\mathrm{Al}^{3+}$ toxicity in field, demonstrating great representativeness when associated to the field condition (Portaluppi et al., 2010).

The $\mathrm{Al}^{3+}$ toxicity is a more serious problem in acid subsoil, due to the correction difficulty, not allowing 
the root deepening, decreasing the tolerance to dryland and interfering in the absorption and translocation of nutrients such as phosphorus, calcium, magnesium, and iron (Horst et al., 2010; Kochian et al., 2004). Great efforts are provided for the comprehension of the responsible mechanisms by the tolerance to $\mathrm{Al}^{3+}$ toxicity in plants. The inheritance mechanisms are different depending on the species and varieties (Sánchez Chacón et al., 2000). Genes present in the short arm of the chromosome $3 \mathrm{R}$ in triticale induced the organic acid exudation, which is the principal mechanism of $\mathrm{Al}^{3+}$ tolerance (Ma et al., 2000).

Many species have developed mechanisms to improve survival in acidic soils (Ryan et al., 2011). These mechanisms were comprehended and divided into those capable of excluding or hindering the penetration of $\mathrm{Al}^{3+}$ by root (exclusion or resistance mechanisms) and those that allow the entry of $\mathrm{Al}^{3+}$ in the plants, which were later housed in the tissue after penetration symplast (tolerance mechanisms).

Because this is extremely important character, chiefly to the winter cereal, the $\mathrm{Al}^{3+}$ tolerance has presented simple inheritance determined by a dominant gene in bread wheat (Camargo et al., 1999), in durum wheat (Del Guercio and Camargo, 2011) and oat (Sánchez Chacón et al., 2000). However some studies show quantitative inheritance in rice (Ferreira et al., 1997) and wheat (Aniol, 1990).

To know the magnitude of genetic effects, this study had the objective to evaluate the differential behavior of Mexican triticale lines when it comes to the $\mathrm{Al}^{3+}$ tolerance and toxicity, as well as verifying the genetic tolerance control and the genetic parameters involved in the root growth, in nutrient solution.

\section{MATERIAL AND METHODS}

Twenty triticale genotypes (Table 1), plus the control cultivar of bread wheat: BH-1146 (tolerant) and Anahuac (sensitive) were evaluated in laboratory conditions, for tolerance to $\mathrm{Al}^{3+}$ toxicity in concentrations $0,3,6,9,12$ and $15 \mathrm{mg} \mathrm{L}^{-1}$, using nutrient solutions. The solutions were aerated dialy and maintained at ph 4.0. The experimental design was in randomized blocks with subsampling in the plots, with the plots of six different concentrations and, the subplots, the genotypes, with four replications. Data were evaluated, considering the average of the central primary growth root of five seedlings of each genotype, in 72 hours growing in complete nutrient solutions without aluminum, following 48 hours growing in treatment solutions containing six different aluminum levels. Those which presented root growth were considered tolerant, whereas those with root growth paralyzed were considered sensitive (Camargo et al., 2006).

In order to make up the genetic study four triticale parents, which presented variability about tolerance to $\mathrm{Al}^{3+}$ toxicity, were used, the genotypes $3\left(\mathrm{P}_{1}\right)$ and $8\left(\mathrm{P}_{2}\right)$, aluminum tolerant and the genotype $14\left(\mathrm{P}_{3}\right)$ and the IAC 5 - Canindé $\left(\mathrm{P}_{4}\right)$ used as sensitive (Table 1). After selection, those were carry out in screen house to obtain the generations $\mathrm{F}_{1}, \mathrm{~F}_{2}$ and the backcrossing $\mathrm{RC}_{1}$ and $\mathrm{RC}_{2}$.

Table 1. Origin and Genealogy of the Genotypes evaluated in Field in Triticale Trial

\begin{tabular}{|c|c|c|}
\hline Genotypes & Origin & Genealogy \\
\hline 1 & $38^{\circ}$ ITYN-TA-07-4 & FAHAD 5 \\
\hline 2 & $38^{\circ}$ ITYN-TA-07-19 & DAHBI/COATI 1/3/CT775.81/ARDI 1//ANOAS 1 \\
\hline $3\left(P_{1}\right)$ & $38^{\circ}$ ITYN-TA-07-24 & T1502 WG/MOLOC 4//RHINO 3/BULL 1-1/3/FAHAD 5²/RHINO 1R.1D 5+10 5D’5B' \\
\hline 4 & $38^{\circ}$ ITYN-TA-07-26 & T1502 WG/MOLOC 4//RHINO 3/ BULL 1-1/3/POLLMER 3/FOCA 2-1 \\
\hline 5 & $38^{\circ}$ ITYN-TA-07-31 & DAHBI/COATI 1//ASAD/FAHAD 1 \\
\hline 6 & $38^{\circ}$ ITYN-TA-07-32 & DAHBI 6/3/ARDI 1/TOPO1419//ERIZO 9/4/ERIZO 11*2/MILAN \\
\hline 7 & $38^{\circ}$ ITYN-TA-07-33 & DAHBI 6/3/ARDI 1/TOPO1419//ERIZO 9/4/RONDO/2*ERIZO 11 \\
\hline $8\left(P_{2}\right)$ & $38^{\circ}$ ITYN-TA-07-34 & DAHBI 6/3/ARDI 1/TOPO1419//ERIZO 9/4/RONDO/2*ERIZO 11 \\
\hline 9 & $38^{\circ}$ ITYN-TA-07-6 & DAHBI 6/3/ARDI 1/TOPO1419//ERIZO 9 \\
\hline 10 & $38^{\circ}$ ITYN-TA-07-15 & 804/BAT/3/MUSX/LYNX//STIER 12-3/4/VARSA 3-1/5/FAHAD 8-1*2//HARE 263/CIVET \\
\hline 11 & $38^{\circ}$ ITYN-TA-07-21 & DAHBI 6/3/ARDI 1/TOPO1419//ERIZO 9/4/NIMIR 1/HARE 265//ERIZO 9 \\
\hline 12 & $38^{\circ}$ ITYN-TA-07-37 & FAHAD 4/FARAS 1/5/247/320//BGL/3/MUSX/LYNX/4/ RHINO 9/6/FD 693/2*FAHAD 4 \\
\hline 13 & $38^{\circ}$ ITYN-TA-07-9 & ANOAS 5/STIER 13//RHINO 3/BULL 1-1 \\
\hline $14\left(P_{3}\right)$ & $38^{\circ}$ ITYN-TA-07-10 & BULL 10/MANATI 1//COATI 1/3/POLLMER 3.5.1 \\
\hline 15 & $38^{\circ}$ ITYN-TA-07-11 & POPP1 2/CAAL//POLLMER 3.5.1 \\
\hline 16 & $38^{\circ}$ ITYN-TA-07-14 & POLLMER 3/FOCA 2-1//POLLMER 4/3/FAHAD 8-2 \\
\hline 17 & $38^{\circ}$ ITYN-TA-07-23 & DAHBI 6/3/ARDI 1/TOPO1419//ERIZO 9/4/SONNI 3 \\
\hline 18 & $38^{\circ}$ ITYN-TA-07-29 & BULL 10/MANATI//FARAS/CMH84.4414 \\
\hline 19 & $38^{\circ}$ ITYN-TA-07-30 & $\begin{array}{l}\text { DAHBI 6/3/ARDI 1/TOPO 1419//ERIZO 9/5/6TA876/6TB164//PND-T/RHM/3/TESMO } \\
\text { 2/4/2*ERIZO } 12\end{array}$ \\
\hline $20\left(P_{4}\right)$ & IAC 5 - Canindé & LT 978.82/ASAD//TARASCA \\
\hline
\end{tabular}

ITYN = International Triticale Yield Nursery (CIMMYT, Mexico) 
The germinated seeds of each parent and their future generations were sowed in nutrient solution, having the concentration of $6 \mathrm{mg} \mathrm{L}^{-1}$ of $\mathrm{Al}^{3+}$ using the same technique mentioned before. The concentration was chosen based on studies which showed this level to be efficient for the separation of $\mathrm{Al}^{3+}$ tolerant and sensitive plants. In the six replications, the frequencies of tolerant and sensitive plants were computed based on tolerance reactions (root growth) and sensitive (paralysation). The Chi-Square test was used to compare the frequencies obtained and expected to the segregation hypothesis of a pair of alleles with dominance effect.

In order to obtain the estimates of genetic parameters of the root growth, it was evaluated in terms of individual plants, in all parents and their respective hybrid combinations and generations, the growth of the central primary root after 72 hours of growth in complete nutrients solution, in millimeters, which was followed by a 48 hour treatment in nutrient solution containing $6 \mathrm{mg} \mathrm{L}^{-1}$ of $\mathrm{Al}^{3+}$, with the exception of the crossing between $\mathrm{P}_{3}$ and $\mathrm{P}_{4}$ both are sensitive, because they showed, in all evaluated generations seedlings with paralysation in root growth after a treatment solution in presence of $\mathrm{Al}^{3+}$ in $6 \mathrm{mg} \mathrm{L}^{-1}$ concentration.

Using the computational program Genes (Cruz, 2006), the following parameters were estimated: phenotypic, genotypic, environmental, and additive variation; heritability estimated in the broad sense and narrow sense and the number of genes involved in the character control.

\section{RESULTS AND DISCUSSIONS}

The root growth average of the twenty triticale genotypes, besides the two control bread wheat cultivars BH-1146 (tolerant) and Anahuac (sensitive) are presented in table 2. In the treatment solution without aluminum all genotypes presented growth in the central primary root, being observed only differences referred to the genotype genetic constitution.

It was also verified that as concentration was increased, there was a tendency to reduce the average root growth, making it possible to list the genotypes according to the reaction to $\mathrm{Al}^{3+}$ toxicity. This reduction was already expected considering that all the genotypes evaluated in nutrient solution contained increasing concentrations of aluminum presented root growth reduction in more elevated doses (Portaluppi et al., 2010).

In nutrient solution containing $3 \mathrm{mg} \mathrm{L}^{-1}$ of $\mathrm{Al}^{3+}$ only the line 14 and the control cultivar Anahuac were sensitive, due to the fact that these genotypes exhibit an irreversible of the central primary root growth in this concentration. The lines 13, 17 and the IAC 5-Canindé cultivar presented sensibility in nutrient solution containing $6 \mathrm{mg} \mathrm{L}^{-1}$ of $\mathrm{Al}^{3+}$, agreeing with the ones obtained by Camargo et al. (2006).

The genotypes evaluated did not present sensibility in nutrient solution containing $9 \mathrm{mg} \mathrm{L}^{-1}$ of $\mathrm{Al}^{3+}$, except the already sensitive to 3 and $6 \mathrm{mg} \mathrm{L}^{-1}$ of $\mathrm{Al}^{3+}$, demonstrating tolerance of these genotypes in elevated concentrations.

Table 2. Average root growth of twenty triticale genotypes after six different aluminum concentrations (an average of four repetitions)

\begin{tabular}{|c|c|c|c|c|c|c|}
\hline \multirow[b]{2}{*}{ Genotypes } & \multicolumn{6}{|c|}{ Aluminum concentration ( $\mathrm{mg} \mathrm{L}^{-1}$ ) } \\
\hline & 0 & 3 & 6 & 9 & 12 & 15 \\
\hline & & & & & & \\
\hline 1 & 96.2 & 67.6 & 48.4 & 45.8 & 32.2 & 23.5 \\
\hline 2 & 101.2 & 77.2 & 54.2 & 45.7 & 29.7 & 26.1 \\
\hline 3 & 97.0 & 63.8 & 48.4 & 36.4 & 33.4 & 25.0 \\
\hline 4 & 99.1 & 71.2 & 55.5 & 45.4 & 38.6 & 29.2 \\
\hline 5 & 93.6 & 67.6 & 51.1 & 38.2 & 23.4 & 21.6 \\
\hline 6 & 82.3 & 60.5 & 41.9 & 34.2 & 23.0 & 20.7 \\
\hline 7 & 113.1 & 82.7 & 59.4 & 50.1 & 37.4 & 30.6 \\
\hline 8 & 86.9 & 58.9 & 41.6 & 30.4 & 28.9 & 26.3 \\
\hline 9 & 106.4 & 73.1 & 46.9 & 34.4 & 26.8 & 21.4 \\
\hline 10 & 111.8 & 58.7 & 50.2 & 34.0 & 22.3 & 11.5 \\
\hline 11 & 92.2 & 57.6 & 45.7 & 32.0 & 25.9 & 17.9 \\
\hline 12 & 87.6 & 66.8 & 51.1 & 29.4 & 21.5 & 12.4 \\
\hline 13 & 99.3 & 0.7 & 0.0 & 0.0 & 0.0 & 0.0 \\
\hline 14 & 96.5 & 0.0 & 0.0 & 0.0 & 0.0 & 0.0 \\
\hline 15 & 103.9 & 35.0 & 5.1 & 3.4 & 0.0 & 0.0 \\
\hline 16 & 98.0 & 57.3 & 30.6 & 15.8 & 2.5 & 0.0 \\
\hline 17 & 110.1 & 0.9 & 0.0 & 0.0 & 0.0 & 0.0 \\
\hline 18 & 107.9 & 60.5 & 29.1 & 14.5 & 11.0 & 0.0 \\
\hline 19 & 85.8 & 52.3 & 36.6 & 27.5 & 13.0 & 4.2 \\
\hline IAC-5 & 96.8 & 0.2 & 0.0 & 0.0 & 0.0 & 0.0 \\
\hline BH-1146 & 102.9 & 70.4 & 52.5 & 40.0 & 11.6 & 5.5 \\
\hline Anahuac & 92.6 & 0.0 & 0.0 & 0.0 & 0.0 & 0.0 \\
\hline
\end{tabular}


The line 15 demonstrated sensibility in nutrient solution containing $12 \mathrm{mg} \mathrm{L}^{-1}$ of $\mathrm{Al}^{3+}$ and the lines 16 and 18 were sensitive in nutrient solution containing $15 \mathrm{mg} \mathrm{L}^{-1}$ of $\mathrm{Al}^{3+}$. In this concentration, the other triticale lines evaluated and the control cultivar of wheat $\mathrm{BH}-1146$ were tolerant to aluminum for presenting central primary root growth. Due to this high tolerance, these genotypes will be able to be, in the future, recommended to be cultivated in acid soil and to be used as genetic sources in triticale breeding programs.

The genetic study according to tolerance to toxicity of $\mathrm{Al}^{3+}$ to $6 \mathrm{mg} \mathrm{L}^{-1}$ in nutrient solutions of seedlings of the parents $\mathrm{P}_{1}, \mathrm{P}_{2}, \mathrm{P}_{3}$ e $\mathrm{P}_{4}$, as well as crossings in generations $\mathrm{F}_{1}$ 's e $\mathrm{F}_{2}$ 's, and the backcrosses $\mathrm{RC}_{1}$ 's and $\mathrm{RC}_{2}$ 's, expressed in number of plant tolerant $(\mathrm{T})$ and sensitive $(\mathrm{S})$, are in tables 3 and 4, respectively.

All the seedlings of the parents $\mathrm{P}_{3}$ e $\mathrm{P}_{4}$ were sensitive to the presence of $6 \mathrm{mg} \mathrm{L}^{-1}$ in treatment solutions, presented an irreversible root growth after remaining 48 hours in this solution. The parents $\mathrm{P}_{1}$ and $\mathrm{P}_{2}$ exhibit tolerance to this concentration of aluminum toxicity, presenting root growth even after being 48 hours in treatment solution.

The generations $\mathrm{F}_{1}$ showed all seedlings tolerant, except crossing between the parents $\mathrm{P}_{3}$ and $\mathrm{P}_{4}$ (Table 3 ). In the crossings where at least one tolerant parent was one of the parents $\left(\mathrm{P}_{1} \times \mathrm{P}_{3}, \mathrm{P}_{1} \times \mathrm{P}_{4}, \mathrm{P}_{2} \times \mathrm{P}_{3}\right.$ and $\left.\mathrm{P}_{2} \times \mathrm{P}_{4}\right)$, it was showed tolerance to $\mathrm{Al}^{3+}$ in all progenies evaluated, suggesting that the parents $P_{1}$ and $P_{2}$ carry a pair of dominant alleles and that the inheritance to the toxicity of $\mathrm{Al}^{3+}$ is monogenic, data also found by Del Guercio and Camargo (2011) in durum wheat.

In the generation $\mathrm{F}_{2}$ it was observed the segregation 3:1 in all inbred lines involving tolerant and sensitive parent
(Table 3). In the inbred line $\mathrm{P}_{1} \times \mathrm{P}_{3}$ it was observed the segregation of 267 tolerant plants to 105 sensitive plants, with a value of $15 \%$ probability of not having occurred randomly. The inbred line $\mathrm{P}_{1} \times \mathrm{P}_{4}$ (0.03), exhibited 257 tolerant and 109 sensitive; the $\mathrm{F}_{2}$ inbred line $\mathrm{P}_{2} \times \mathrm{P}_{3}$ exhibited segregation of 281 tolerant to 94 sensitive, indicating $100 \%$ of probability. The $\mathrm{F}_{2}$ inbred line $\mathrm{P}_{2} \times \mathrm{P}_{4}(0.06)$, presented 261 tolerant plants and 108 sensitive.

In $\mathrm{RC}_{1}$ 's where the tolerant parents were recurrent, all the seedlings presented root growth after remaining in the concentration $6 \mathrm{mg} \mathrm{L}^{-1}$ of $\mathrm{Al}^{3+}$ (Table 4). In this generation only the $\mathrm{RC}_{1}\left(\mathrm{P}_{3} \times \mathrm{P}_{4}\right) \times \mathrm{P}_{3}$ demonstrated all the sensitive seedlings.

The $\mathrm{RC}_{2}\left(\mathrm{P}_{1} \times \mathrm{P}_{2}\right) \times \mathrm{P}_{2}$, with all the tolerant seedlings and $\left(\mathrm{P}_{3} \times \mathrm{P}_{4}\right) \times \mathrm{P}_{4}$ with all the sensitive, showed proportion $1: 0$ and $0: 1$ respectively, with probability values of 1.00 , indicating $100 \%$ probability of not having occurred randomly (Tabela 4).

The backcross $\left(\mathrm{P}_{1} \times \mathrm{P}_{3}\right) \times \mathrm{P}_{3}$ showed 79 tolerant seedlings and 119 sensitive, with expected proportion of $1: 1$, with probability value of 0.004 . Probably, this fact occurred due to low vigor presented by seeds of this cross, because when they were put to germinate, originated less developed seedlings, when compared to other populations. The low vigor of seeds of this cross may be linked to genetic incompatibility between the parents involved, interfering in the seedling development.

It was observed a segregation of 98 tolerant seedlings to 100 sensitive in the backcross $\left(\mathrm{P}_{1} \times \mathrm{P}_{4}\right) \times \mathrm{P}_{4}$; of 100 tolerant seedlings to 92 sensitive in $\left(\mathrm{P}_{2} \times \mathrm{P}_{3}\right) \times \mathrm{P}_{3}$; and of 101 tolerant seedlings to 96 sensitive in $\left(\mathrm{P}_{2} \times \mathrm{P}_{4}\right) \times \mathrm{P}_{4}$, almost at the

Table 3. Reactions to aluminum toxicity $\left(6 \mathrm{mg} \mathrm{L}^{-1}\right)$ in nutrient solutions of the parents $\mathrm{P}_{1}, \mathrm{P}_{2}, \mathrm{P}_{3}$ and IAC-5 $\left(\mathrm{P}_{4}\right)$ and the generations $\mathrm{F}_{1}$, $\mathrm{F}_{2}$, expressed in numbers of tolerant plants $(\mathrm{T})$ and sensitive plants $(\mathrm{S})$ to the aluminum toxicity

\begin{tabular}{|c|c|c|c|c|c|c|}
\hline \multirow{2}{*}{$\begin{array}{c}\text { Cultivar or } \\
\text { Crosses }\end{array}$} & \multirow{2}{*}{$\begin{array}{l}\text { Parents } \\
\text { reactions }\end{array}$} & \multicolumn{2}{|c|}{ Observed plants } & \multirow{2}{*}{$\begin{array}{c}\text { Expected } \\
\text { Proportion } \\
\text { T : S }\end{array}$} & \multirow[b]{2}{*}{$x^{2}$} & \multirow[b]{2}{*}{ Probability $^{(1}$} \\
\hline & & $T\left(n^{0}\right)$ & $S\left(n^{\circ}\right)$ & & & \\
\hline $\mathrm{P}_{1}$ & $\mathrm{~T}$ & 126 & 0 & & & \\
\hline $\mathrm{P}_{2}$ & $\mathrm{~T}$ & 126 & 0 & & & \\
\hline $\mathrm{P}_{3}$ & S & 0 & 135 & & & \\
\hline $\mathrm{P}_{4}$ & $\mathrm{~S}$ & 0 & 126 & & & \\
\hline $\mathrm{F}_{1}\left(\mathrm{P}_{1} \times \mathrm{P}_{2}\right)$ & $\mathrm{T}$ & 177 & 0 & $1: 0$ & 0.00 & 1.00 \\
\hline $\mathrm{F}_{1}\left(\mathrm{P}_{1} \times \mathrm{P}_{3}\right)$ & $\mathrm{T}$ & 186 & 0 & $1: 0$ & 0.00 & 1.00 \\
\hline $\mathrm{F}_{1}\left(\mathrm{P}_{1} \times \mathrm{P}_{4}\right)$ & $\mathrm{T}$ & 186 & 0 & $1: 0$ & 0.00 & 1.00 \\
\hline $\mathrm{F}_{1}\left(\mathrm{P}_{2} \times \mathrm{P}_{3}\right)$ & $\mathrm{T}$ & 183 & 0 & $1: 0$ & 0.00 & 1.00 \\
\hline $\mathrm{F}_{1}\left(\mathrm{P}_{2} \times \mathrm{P}_{4}\right)$ & $\mathrm{T}$ & 192 & 0 & $1: 0$ & 0.00 & 1.00 \\
\hline$F_{1}\left(P_{3} \times P_{4}\right)$ & S & 0 & 186 & $0: 1$ & 0.00 & 1.00 \\
\hline $\mathrm{F}_{2}\left(\mathrm{P}_{1} \times \mathrm{P}_{2}\right)$ & $\mathrm{T} \times \mathrm{T}$ & 369 & 0 & $1: 0$ & 0.00 & 1.00 \\
\hline $\mathrm{F}_{2}\left(\mathrm{P}_{1} \times \mathrm{P}_{3}\right)$ & $\mathrm{T} \times \mathrm{S}$ & 267 & 105 & $3: 1$ & 2.06 & 0.15 \\
\hline $\mathrm{F}_{2}\left(\mathrm{P}_{1} \times \mathrm{P}_{4}\right)$ & $\mathrm{T} \times \mathrm{S}$ & 257 & 109 & $3: 1$ & 4.46 & 0.03 \\
\hline $\mathrm{F}_{2}\left(\mathrm{P}_{2} \times \mathrm{P}_{3}\right)$ & $\mathrm{T} \times \mathrm{S}$ & 281 & 94 & $3: 1$ & 0.00 & 1.00 \\
\hline $\mathrm{F}_{2}\left(\mathrm{P}_{2} \times \mathrm{P}_{4}\right)$ & $\mathrm{T} \times \mathrm{S}$ & 261 & 108 & $3: 1$ & 3.58 & 0.06 \\
\hline $\mathrm{F}_{2}\left(\mathrm{P}_{3} \times \mathrm{P}_{4}\right)$ & $S \times S$ & 0 & 366 & $0: 1$ & 0.00 & 1.00 \\
\hline
\end{tabular}

(1) Probability of success between the obtained and expected frequencies by the hypothesis of the segregation of a pair of alleles 
expected proportion 1:1, with probability values of $89 \%, 56 \%$ and $72 \%$, respectively, for not having occurred randomly.

From the results it would be possible to consider that the parents $\mathrm{P}_{1}$ and $\mathrm{P}_{2}$ would have the genotype combination $\mathrm{AA}$ (tolerant), the $\mathrm{P}_{3}$ and $\mathrm{P}_{4}$ aa (sensitive). The crosses between tolerant $\mathrm{x}$ sensitive parents $\left(\mathrm{F}_{1}\right)$ would be $\mathrm{Aa}$ (Tolerant) and the $\mathrm{F}_{2}$ 's would be the segregation 1/4 AA (tolerant), 2/4 Aa (tolerant) and $1 / 4$ aa (sensitive). The $\mathrm{RC}_{1} \mathrm{~F}_{1}$ would have the segregation $1 / 2 \mathrm{AA}$ (tolerant) and $1 / 2 \mathrm{Aa}$ (tolerant) and the $\mathrm{RC}_{2} \mathrm{~F}_{1}$ would present segregation $1 / 2 \mathrm{Aa}$ (tolerant) and $1 / 2$ aa (sensitive) combining the tolerance inheritance to $\mathrm{Al}^{3+}$ in common wheat (Camargo et al., 1999) and durum wheat (Del Guercio and Camargo, 2011).

The estimations based on variances obtained to the root growth, after remaining in solution containing $6 \mathrm{mg} \mathrm{L}^{-1}$ of $\mathrm{Al}^{3+}$, are in table 5. It is observed that there was predominance of genotype variation about the environmental in all the crosses, showing homogeneity between the values obtained, representing most of the total variance observed.

The genetic variance decomposition demonstrated that the additive variance was the most important component, representing in all crosses the totality or even great part of the genetic variance showed to the root growth, interfering in the dominance effect, which in some cases was negative. The importance of the additive effects in the root growth in $\mathrm{Al}^{3+}$ was also demonstrated by Ferreira et al. (1997) in rice, which they also verified greater estimations of additive variance than genetics. The presence of additive variance conditions the possibility of gaining with the selection of superior homozygotic genotypes from $\mathrm{F}_{2}$ (Ramalho et al., 1993).

Based on the information obtained by the variances, the values for heritability coefficient in broad sense were 63.77 to 91.80 and the heritability in narrow sense were 74.46 to 94.56 , with its respective amplitudes, showing high heritability of the root growth (Table 5). With the exception the cross between $\mathrm{P}_{1}$ and $\mathrm{P}_{2}$, both tolerant in the concentration of $6 \mathrm{mg} \mathrm{L}^{-1}$ of $\mathrm{Al}^{3+}$ and the cross $\mathrm{P}_{3}$ and $\mathrm{P}_{4}$, considered sensitive (absence of root growth after treatment solution), it is possible to suggest that the control of this character is probably governed by one or two genes.

Considering the cross between the tolerant parents, the character showed oligogenic inheritance, different from the data obtained by Aniol (1990) studying different genetic

Table 4. Reactions to the aluminum toxicity $\left(6 \mathrm{mg} \mathrm{L}^{-1}\right)$ in nutrient solutions of backcrosses $\left(\mathrm{RC}_{1}\right.$ 's) and $\left(\mathrm{RC}_{2}\right.$ 's), expressed in number of tolerant plants $(\mathrm{T})$ and number of sensitive plants $(\mathrm{S})$ to the aluminum toxicity

\begin{tabular}{|c|c|c|c|c|c|c|}
\hline \multirow{2}{*}{$\begin{array}{l}\text { Cultivar or } \\
\text { Crosses }\end{array}$} & \multirow{2}{*}{$\begin{array}{l}\text { Parents } \\
\text { reactions }\end{array}$} & \multicolumn{2}{|c|}{ Observed plants } & \multirow{2}{*}{$\begin{array}{c}\text { Expected } \\
\text { proportion } \\
T: S\end{array}$} & \multirow[b]{2}{*}{$x^{2}$} & \multirow[b]{2}{*}{ Probability ${ }^{(1)}$} \\
\hline & & $T\left(n^{\circ}\right)$ & $S\left(n^{\circ}\right)$ & & & \\
\hline$R C_{1}\left(P_{1} \times P_{2}\right) \times P_{1}$ & $(T \times T) \times T$ & 195 & 0 & $1: 0$ & 0.00 & 1.00 \\
\hline$R C_{1}\left(P_{1} \times P_{3}\right) \times P_{1}$ & $(T \times S) \times T$ & 176 & 0 & $1: 0$ & 0.00 & 1.00 \\
\hline $\mathrm{RC}_{1}\left(\mathrm{P}_{1} \times \mathrm{P}_{4}\right) \times \mathrm{P}_{1}$ & $(T \times S) \times T$ & 213 & 0 & $1: 0$ & 0.00 & 1.00 \\
\hline$R C_{1}\left(P_{2} \times P_{3}\right) \times P_{2}$ & $(T \times S) \times T$ & 198 & 0 & $1: 0$ & 0.00 & 1.00 \\
\hline$R C_{1}\left(P_{2} \times P_{4}\right) \times P_{2}$ & $(T \times S) \times T$ & 183 & 0 & $1: 0$ & 0.00 & 1.00 \\
\hline$R C_{1}\left(P_{3} \times P_{4}\right) \times P_{3}$ & $(\mathrm{~S} \times \mathrm{S}) \times \mathrm{S}$ & 0 & 192 & $0: 1$ & 0.00 & 1.00 \\
\hline$R C_{2}\left(P_{1} \times P_{2}\right) \times P_{2}$ & $(T \times T) \times T$ & 189 & 0 & $1: 0$ & 0.00 & 1.00 \\
\hline$R C_{2}\left(P_{1} \times P_{3}\right) \times P_{3}$ & $(T \times S) \times S$ & 79 & 119 & $1: 1$ & 8.08 & 0.004 \\
\hline $\mathrm{RC}_{2}\left(\mathrm{P}_{1} \times \mathrm{P}_{4}\right) \times \mathrm{P}_{4}$ & $(T \times S) \times S$ & 98 & 100 & $1: 1$ & 0.02 & 0.89 \\
\hline$R C_{2}\left(P_{2} \times P_{3}\right) \times P_{3}$ & $(T \times S) \times S$ & 100 & 92 & $1: 1$ & 0.33 & 0.56 \\
\hline $\mathrm{RC}_{2}\left(\mathrm{P}_{2} \times \mathrm{P}_{4}\right) \times \mathrm{P}_{4}$ & $(T \times S) \times S$ & 101 & 96 & $1: 1$ & 0.13 & 0.72 \\
\hline$R C_{2}\left(P_{3} \times P_{4}\right) \times P_{4}$ & $(\mathrm{~S} \times \mathrm{S}) \times \mathrm{S}$ & 0 & 183 & $0: 1$ & 0.00 & 1.00 \\
\hline
\end{tabular}

${ }^{(1)}$ Probability of success between the obtained and expected frequencies by the hypothesis of a pair of alleles segregation

Table 5. Estimatives of the phenotypical variance, genotypical, environmental, and additive variances, of heritability in broad sense and narrow sense and the number of genes which control the root growth character (NGC), in mm, obtained from plants in six generations (Parents, $\mathrm{F}_{1}, \mathrm{~F}_{2}, \mathrm{RC}_{1}$ and $\mathrm{RC}_{2}$ ) in triticale

\begin{tabular}{|cccccc}
\hline Parameter & $\mathbf{P}_{1} \mathbf{x} \mathbf{P}_{\mathbf{2}}$ & $\mathbf{P}_{\mathbf{1}} \mathbf{x} \mathbf{P}_{\mathbf{3}}$ & $\mathbf{P}_{\mathbf{1}} \mathbf{x} \mathbf{P}_{\mathbf{4}}$ & $\mathbf{P}_{\mathbf{2}} \mathbf{x} \mathbf{P}_{\mathbf{3}}$ & $\mathbf{P}_{\mathbf{2}} \mathbf{x} \mathbf{P}_{4}$ \\
\hline$\sigma_{\mathrm{F}}^{2}$ & 147.03 & 324.21 & 359.16 & 394.37 & 451.39 \\
\hline$\sigma_{\mathrm{G}}^{2}$ & 93.76 & 287.67 & 325.54 & 360.10 & 414.37 \\
\hline$\sigma_{\mathrm{E}}^{2}$ & 53.27 & 36.54 & 33.62 & 34.27 & 37.02 \\
$\sigma_{\mathrm{A}}^{2}$ & 129.81 & 306.57 & 267.43 & 367.01 & 404.92 \\
\hline$h^{2}{ }_{\text {BS }}(\%)$ & 63.77 & 88.73 & 90.64 & 91.31 & 91.80 \\
\hline$h^{2}{ }_{\mathrm{NS}}(\%)$ & $88.28 \pm 11.86$ & $94.56 \pm 11.42$ & $74.46 \pm 13.94$ & $93.06 \pm 11.57$ & $89.70 \pm 11.66$ \\
\hline $\mathrm{NGC}$ & 3 & 1 & 2 & 1 & 1 \\
\hline
\end{tabular}


sources in wheat. However, Ferreira et al. (1997) suggested that the root growth in rice was conditioned to four genes, with quantitative behavior, data also obtained by Camargo and Ferreira Filho (2005) evaluating two parents contrasting to the root growth.

These estimates are indicators of the genetic nature and probability to obtain superior genotypes when it comes to the root growth in triticale. Few genes, low environment influence and high proportion of the additive variance in expressing the genetic variance imply more facility to improve to obtain genotypes with tolerance to aluminum toxicity, besides allowing early selection in the first segregating generations.

\section{CONCLUSION}

Triticale genotypes present differential reaction to tolerance in the presence of aluminum toxicity in nutrient solution. The line 15 were sensitive in nutrient solution containing $12 \mathrm{mg} \mathrm{L}^{-1}$ of $\mathrm{Al}^{3+}$ and the lines 16 and 18 in $15 \mathrm{mg} \mathrm{L}^{-1}$ of $\mathrm{Al}^{3+}$. In this concentration, the other triticale lines evaluated and the control cultivar of wheat $\mathrm{BH}-1146$ were tolerant to aluminum. Due to this high tolerance, these genotypes will be able to be recommended to be cultivated in acid soil and to be used as genetic sources in triticale breeding programs.

The aluminum tolerance in triticale has simple inheritance and is governed by a dominant gene.

The selection for the root growth should be done in the first segregating generations, due to the oligogenic behavior in the character control.

\section{ACKNOWLEDGEMENTS}

To the Coordination for the Enhancement of Higher Educational Personnel (CAPES) for granting the doctorate scholarship.

\section{REFERENCES}

ANIOL, A. Genetics of tolerance to aluminium in wheat (Triticum aestivum L. Thell). Plant and Soil, v.23, p.223-227, 1990. http:// dx.doi.org/10.1007/BF00011272

BAIER, A.C. Melhoramento do triticale. In: BORÉM, A. (Ed.). Melhoramento de espécies cultivadas. Viçosa, 1999. p.573-588.

CAMARGO, C.E.O.; FERREIRA FILHO, A.W.P.; FELICIO, J.C. Inheritance of aluminum tolerance in wheat. Scientia Agricola, v.56, p.429-435, 1999. http://dx.doi.org/10.1590/S010390161999000200024
CAMARGO, C.E.O.; FELICIO, J.C.; FERREIRA FILHO, A.W.P.; LOBATO, M.T.V. Tolerância de genótipos de trigo comum, trigo duro e triticale à toxicidade de alumínio em solução nutritivas. Bragantia, v.65, p.43-53, 2006. http://dx.doi.org/10.1590/S000687052006000100007

CAMARGO, C.E.O.; FERREIRA FILHO, A.W.P. Genetic control of wheat seedling root growth. Scientia Agricola, v.62, p.325-330, 2005. http://dx.doi.org/10.1590/S0103-90162005000400004

CRUZ, C.D. Programa Genes. versão Windows Biometria. Viçosa: Editora UFV, 2006. 382p.

DEL GUERCIO, A.M.F.; CAMARGO, C.E.O. Herança da tolerância à toxicidade de alumínio em trigo duro. Bragantia, v.70, p.775-780, 2011.

FERREIRA, R.P.; SEDIYAMA, C.S.; CRUZ, C.D.; FREIRE, M.S. Herança da tolerância à toxidez de alumínio em arroz baseada em análises de médias e variâncias. Pesquisa Agropecuária Brasileira, v.32, p.509-515, 1997

HORST, W.J.; WANG, Y.X.; ETICHA, D. The role of the root apoplast in aluminium-induced inhibition of root elongation and in aluminium resistance of plants: a review. Annals of Botany, v.106, p.185-197, 2010. http://dx.doi.org/10.1093/aob/mcq053

KOCHIAN, L.V.; HOEKENGA, O.A.; PINEROS, M.A. How do crop plants tolerate acid soils. Mechanisms of aluminum tolerance and phosphorous efficiency. Annual Review of Plant Biology, v.55, p.459-493, 2004. http://dx.doi.org/10.1146/annurev. arplant.55.031903.141655

MA, J.F.; TAKETA, S.; YANG, Z.M. Aluminum tolerance genes on the short arm of chromosome $3 \mathrm{r}$ are linked to organic release in triticale. Plant Physiology, v.122, p.687-694, 2000. http://dx.doi. org/10.1104/pp.122.3.687

NIEDZIELA, A.; BEDNAREK, P.T.; CICHY, H.; BUDZIANOWSKI, G.; KILIAN, A.; ANIOL, A. Aluminum tolerance association mapping in triticale. Bmc Genomics, v.13, p.67-75, 2012. http:// dx.doi.org/10.1186/1471-2164-13-67

PORTALUPPI, R.; BRAMMER, S.P.; MAGALHÃES, J.V.; COSTA, C.T.; CAIEIRÃO, E.; NASCIMENTO JUNIOR, A.; SILVA JUNIOR, J.P. Tolerância de genótipos de cereais de inverno ao alumínio em cultivo hidropônico e em campo. Pesquisa Agropecuária Brasileira, v.45, p.178185, 2010. http://dx.doi.org/10.1590/S0100-204X2010000200009

RAMALHO, M.A.P.; SANTOS. J.B.; ZIMMERMANN, M.J.O. Genética quantitativa em plantas autógamas: aplicaçôes ao melhoramento do feijoeiro. Goiânia: UFG, 1993. 171p.

RYAN, P.R.; TYERMAN, S.D.; SASAKI, T.; FURUICHI, T.; YAMAMOTO, Y.; ZHANG, W.H.; DELHAIZE, E. The identification of aluminium-resistance genes provides opportunities for enhancing crop production on acid soils. Journal of Experimental Botany, v.62, p.9-20, 2011. http://dx.doi.org/10.1093/jxb/erq272

SÁNCHEZ CHACÓN, C.D.; FEDERIZZI, L.C.; MILACH, S.C.K.; PACHECO, M.T. Variabilidade genética e herança à toxicidade do alumínio em aveia. Pesquisa Agropecuária Brasileira, v.35, p.17971808, 2000. http://dx.doi.org/10.1590/S0100-204X2000000900012 